\title{
Evaluating vacuum and steam process on hardwood veneer logs for export
}

\author{
Zhangjing Chen ${ }^{1} \cdot$ Marshall S. White ${ }^{1} \cdot$ Ron Mack $^{2}$
}

Received: 16 January 2016/Published online: 22 November 2016

(C) Springer-Verlag Berlin Heidelberg 2016

\begin{abstract}
There is an immediate need to develop and adopt new treatment technologies for eliminating insect pest and tree pathogens from veneer logs moved in trade. This is largely due to the current phase-out of methyl bromide and the uncertainty associated with the efficacy of potential alternatives. Vacuum and steam in combination has a proven and reliable record for commercially sanitizing a variety of commodities, including cotton, spices and textiles among others. This study was designed to evaluate basic parameters of vacuum and steam application on five high value hardwood veneer $\log$ species in an effort to ascertain the feasibility of continued treatment development. Relative heating rates to log center, damage and value loss assessment due to treatment, and overall energy used during treatment were recorded for logs treated individually in a flexible polymer chamber. At $200 \mathrm{~mm} \mathrm{Hg}$ vacuum, time to reach $56^{\circ} \mathrm{C}$ for $30 \mathrm{~min}$ to core ranged from 17 to $29 \mathrm{~h}$, depending on density and log diameter. End checking varied by species, but veneer sawn from logs was largely unaffected in terms of yield and value. Energy used during treatments ranged from 54 to $205 \mathrm{kWh}$ for individual logs. Results suggest that vacuum and steam as a phytosanitary treatment for hardwood veneer logs has potential and should be explored further.
\end{abstract}

Zhangjing Chen

chengo@vt.edu

1 Department of Sustainable Biomaterials, Brooks Forest Products Center, Virginia Polytechnic Institute and State University, 1650 Research Center Road, Blacksburg, VA 24061, USA

2 Otis Laboratory, USDA-APHIS-PPQ, 1398 WestTruck Road, Buzzards Bay, MA 02542, USA

\section{Introduction}

Non-indigenous forest pests have caused extensive damage to US forest ecosystems. The chestnut blight fungus (Cryphonectria parasitica), the Dutch elm disease fungi (Ophiostoma novo-ulmi and O. ulmi) and the gypsy moth (Lymantria dispar) have dramatically altered rural and urban forest landscapes in the last century. Such invasive plant pathogenic fungi, nematodes and insect pests are often introduced through importation of logs, lumber and solid wood packing materials (Fleming et al. 2005). Introductions of the Asian longhorned beetle (Anoplophora glabripennis) (Fleming et al. 2005) and the emerald ash borer (Agrilus planipennis) (Haack et al. 2002) in the past two decades have reinforced the need for increased protective measures as trade and associated risk have greatly increased.

In an effort to prevent the global spread of forest pests, the international community has adopted ISPM-15 as a regulatory measure to reduce the risk of invasive pest introduction through the solid wood packing material (SWPM) pathway (IPPC 2002). ISPM-15 mandates treatment of SWPM through developed schedules using methyl bromide fumigation, conventional heat, or dielectric methods (microwave and radiofrequency) (IPPC 2013). Worldwide regulatory focus on SWPM has greatly reduced the risk of wood pest introductions, particularly since the addition of the bark standard to ISPM-15 in 2009 (IPPC 2009). However, additional pathways involving wood remain problematic. Treatment of whole logs is not presently covered under comprehensive international convention, and the result is a loose arrangement of log treatment schedules that are established between countries engaged in trade. These schedules rely on fumigants, primarily methyl bromide and phosphine, and to a lesser 
extent sulfuryl fluoride. The worldwide phase-out of methyl bromide for phytosanitary use has been well documented (UNEP 2002). Questions regarding adequate fumigant penetration in logs have highlighted the need to find suitable alternative treatments for whole $\operatorname{logs}$ (Michelson 1964; Cross 1992). Conventional hot air heat treatment has a proven application for a number of wood pests in wood products (e.g. firewood) where wood product quality issues are not a concern (Mayfield et al. 2014). Conventional hot air heat is not considered a practical solution for treating veneer $\operatorname{logs}$ due to unacceptable checking and discoloration. Because hardwood logs are an expensive commodity, any candidate treatment must not diminish the quality or value of the log.

For conventional heat treatment, the entire profile of the wood (includes the core) must reach and maintain a minimum temperature of $56{ }^{\circ} \mathrm{C}$ for 30 continuous minutes per ISPM-15 requirements (IPPC 2013). Heating where steam is the heating medium has been shown to be an effective method to reach required temperatures in round and rectangular sections of wood (Simpson 2001). Vacuum and steam in combination has a proven and reliable record for commercially sanitizing a variety of commodities, including cotton, spices and textiles among others.

This study was designed to evaluate the use of vacuum and steam thermal process on veneer logs of five North American hardwood species. The goal was to gauge log tolerance and potential vacuum steam treatment times for the selected species. The specific objectives were to: (1) measure the temperature profile from surface to center of hardwood veneer logs during steam/vacuum treatment; (2) document treatment times required to achieve $56{ }^{\circ} \mathrm{C}$ for $30 \mathrm{~min}$ throughout the profile of the $\log$ (including the core); (3) measure the energy consumed to achieve $56{ }^{\circ} \mathrm{C}$ for $30 \mathrm{~min}$ throughout the profile of the $\log$ (including its core); and (4) document the effect of the steam/vacuum treatment on the quality and yield of veneer produced from treated experimental logs.

\section{Materials and methods}

\subsection{Equipment}

The treatment system consists of a vacuum source (vacuum pump), flexible vacuum chamber, steam generator and steam controller (Fig. 1). A flexible vacuum container, made of high tenacity woven fabrics, coated and impregnated with PVC compounds, was used as the test chamber. The chamber itself is rectangular, and measures $3.35 \times 3.05 \mathrm{~m}^{2}(11 \times 10$ feet $)$ in two dimensions when laid flat. A $45 \mathrm{KW}$ steam boiler manufactured by CAM Industries Inc. (Model 12S) was used to supply the steam.

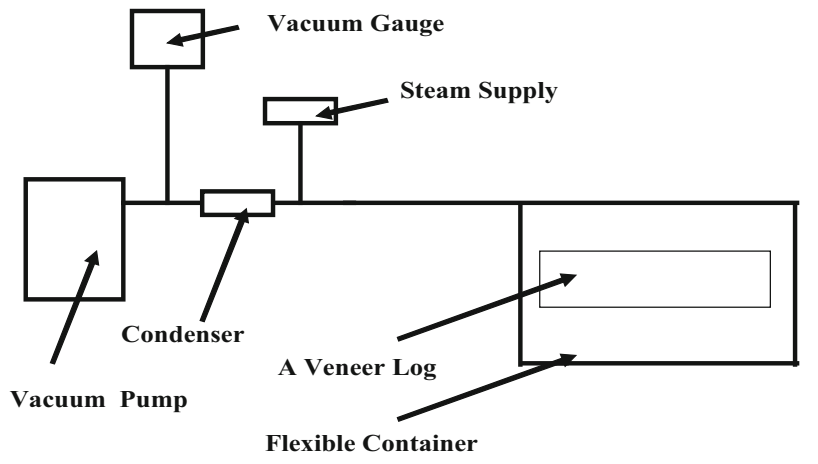

Fig. 1 Schematic diagram of the vacuum/steam treating system

An R5 single-stage, oil-sealed, rotary vane, air-cooled and direct drive vacuum pump (Busch Inc.) was used to remove air from the flexible container. The pump displacement capacity is $0.57 \mathrm{~m}^{3} / \mathrm{min}$ (20 CFM). An HPM-760 Plus Controller (Teledyne and Hastings Co.) was used to monitor the vacuum within the flexible container. Lastly, an air cooled CC-65 condenser (Neslab Corp.) with a capacity to remove 120 watts of heat at $-20{ }^{\circ} \mathrm{C}$ was integrated into the system to condense and collect some of the water vapor and protect the vacuum pump. For monitoring purposes, thermocouples (type $\mathrm{K}$ ) were used to record temperatures within both the flexible chamber and the log.

\subsection{Testing materials and procedure}

The veneer grade hardwood logs were selected from Danzer Veneer Corporation log yards located in Edinburgh, Indiana. Individual logs were procured from different locations in the eastern United States. A total of five tree species of commercial importance were chosen and used in the tests. These included red oak (Quercus spp.), pignut hickory (Carya glabra), black cherry (Prunus serotina), eastern black walnut (Juglans nigra), and yellowpoplar (Liriodendron tulipifera). Four logs of each species were selected for study. One was randomly selected as a control (=non-treated) log and the other three were designated for treatment. Care was taken to handle both control and treated $\operatorname{logs}$ in a similar manner throughout the tests.

In the fall of 2011, the logs were shipped to the Brooks Forest Products Center, Virginia Tech, Blacksburg, Virginia, where they were stacked outside and kept moist with a sprinkler system. Prior to testing, a number of steps were taken to prepare each log. The ends were trimmed back approximately $30.5 \mathrm{~cm}$ (12") to provide a section for oven drying to obtain the moisture content of the log (ASTM D4442-15 2015). The newly exposed log ends were then examined for end checking, and plastic end savers were hammered into place to prevent further checking, if necessary. Exposed log ends were coated with Anchorseal wax emulsion (U.C Coating Co., US) to help minimize moisture 
Table 1 Vacuum/steam test matrix for individual hardwood veneer logs

\begin{tabular}{|c|c|c|c|c|c|c|}
\hline Species & Log ID. & Test number & Larger end dia. $(\mathrm{cm})$ & Small end dia. $(\mathrm{cm})$ & Log initial MC (\%) & Log source \\
\hline \multirow[t]{4}{*}{ Pignut hickory } & 649322 & 3 & 53.3 & 50.8 & 59.8 & Seymour, IN \\
\hline & 649331 & Control sample & 63.5 & 53.3 & 61.4 & Bargersville, IN \\
\hline & 649333 & 6 & 58.4 & 50.8 & 62.6 & Nashville, IN \\
\hline & 649334 & 5 & 55.9 & 48.3 & 76.5 & Dayton, $\mathrm{OH}$ \\
\hline \multirow[t]{4}{*}{ Black cherry } & 629246 & 14 & 48.3 & 45.7 & 50.0 & Cedar Spring, MI \\
\hline & 649137 & 13 & 50.8 & 45.7 & 41.3 & \\
\hline & 649325 & Control sample & 58.4 & 50.8 & & Clinton, MI \\
\hline & 649329 & 10 & 48.3 & 43.2 & 54.7 & Quincy, MI \\
\hline \multirow[t]{4}{*}{ Eastern black walnut } & 619480 & 4 & 61.0 & 45.7 & 93.6 & Greensburg, IN \\
\hline & 619481 & 1 & 45.7 & 43.2 & 98.2 & \\
\hline & 649323 & Control sample & 61.0 & 50.8 & 98.7 & Coggan, IA \\
\hline & 649326 & 7 & 61.0 & 48.3 & 72.4 & Louisiana, MO \\
\hline \multirow[t]{4}{*}{ Yellow poplar } & 646653 & 8 & 48.3 & 45.7 & 81.8 & Gosport, IN \\
\hline & 646676 & Control sample & 63.5 & 45.7 & & \\
\hline & 646690 & 2 & 48.3 & 45.7 & 97.0 & \\
\hline & 646707 & 9 & 48.3 & 43.2 & 62.7 & \\
\hline \multirow[t]{4}{*}{ Red oak } & 649171 & 15 & 50.8 & 45.7 & 75.7 & Rosedale, VA \\
\hline & 649328 & 11 & 55.9 & 45.7 & 69.9 & Akron, IN \\
\hline & 649330 & Control sample & 55.9 & 48.3 & 86.9 & Raven, VA \\
\hline & 704191 & 12 & 50.8 & 45.7 & 81.4 & Mt. Washington, KY \\
\hline
\end{tabular}

loss and additional checking before treatment. Logs were then debarked using a long handled debarking tool. Overall length and end diameters were measured and recorded for each log (Table 1).

Temperature monitoring was accomplished by placing a total of six thermocouples (Type $\mathrm{K}$ ) in a consistent pattern for each individual log test (Fig. 2). Four thermocouples were inserted into $1 / 4$ " holes that were drilled into the logs at specific depths and locations along the length, and the fifth one was placed directly on the log surface. Inserted thermocouples were backfilled with plumbers putty to prevent unwanted steam intrusion into the hole. The remaining thermocouple was placed inside the bag chamber to measure ambient temperature. Thermocouples were connected to the data acquisition system with HP VEE program with Omega signal conditioners (model IDRNTCN) for temperature recording. The flexible chamber was unzipped, the log was lifted into place, and the chamber was then zipped tight for treatment (Fig. 3).

The vacuum pump was turned on, and air was removed from the chamber until a pressure of $200 \mathrm{mmHg}$ was reached. At that point, saturated steam at $110{ }^{\circ} \mathrm{C}$ from boiler was injected into the chamber. Temperatures were recorded at $1 \mathrm{~min}$ intervals. The log surface temperature was maintained at $90{ }^{\circ} \mathrm{C}$ for each test through periodic addition of steam when necessary. When the center probe in the log reached $56{ }^{\circ} \mathrm{C}$, steam introduction was discontinued. The threshold temperature of the center probe was held for an

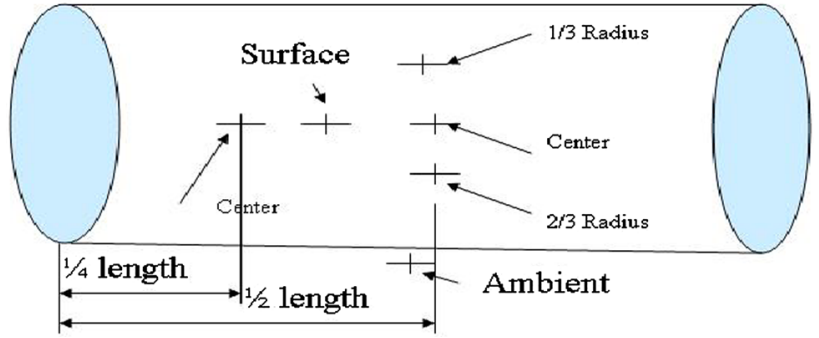

Fig. 2 Standardized thermocouple location in veneer log for monitoring temperature

additional 30 min before the test was concluded. The readings from the steam flow meter were taken before and after each test, and the amount of steam used was calculated. After treatment, the logs were removed from the flexible container and inspected to record any quality changes (e.g. end checking and other visible external defects).

Both the treated and control logs were then shipped to Danzer Veneer Group, Edinburgh, Indiana for veneer slicing. The logs were flitched in half, then conditioned in a hot water vat to $82{ }^{\circ} \mathrm{C}$ per industry standard as a means to soften the wood prior to slicing. The duration of this hot water conditioning varied from 24 to $48 \mathrm{~h}$, depending on wood species. Flitches were then removed from the vats and sliced into veneer. The time interval between log treatment and veneer slicing was approximately 6-8 weeks. The veneers were subsequently dried in a commercial dryer to a final 


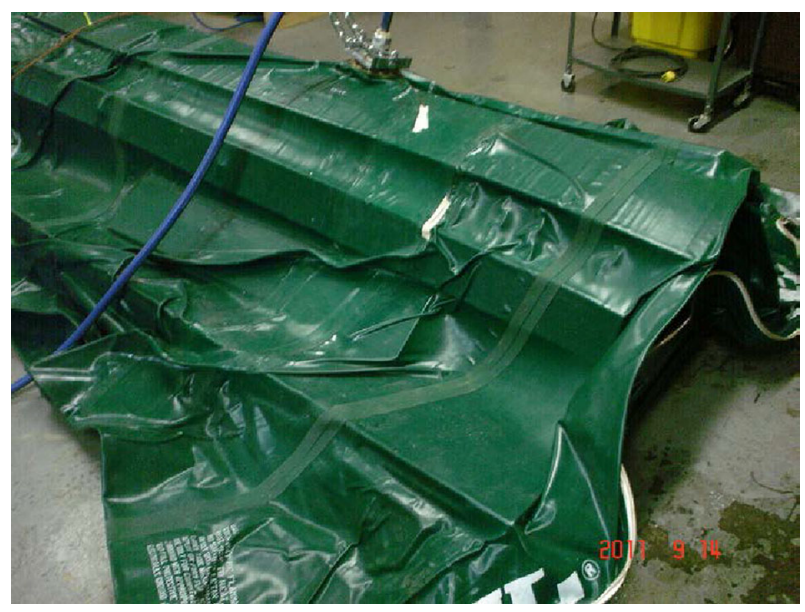

Fig. 3 The flexible vacuum/steam chamber with $\log$ inside and vacuum drawn

moisture content of $7-10 \%$. The one exception was green walnut veneer, which was stacked to air dry for one day per industry standard prior to loading into the commercial dryer as a way to enhance color. After drying, three sample sheets from each flitch were removed and graded for quality by the expert staff at Danzer Veneer.

\section{Results and discussion}

\subsection{Temperature profile}

The temperature profiles obtained for each log treated were very similar in overall appearance (data for two species show, Figs. 4, 5). As expected, monitored locations furthest from the log end and surface (Fig. 2) took greater time to heat.

\subsection{Treatment time}

The treatment times required to achieve $56{ }^{\circ} \mathrm{C}$ for $30 \mathrm{~min}$ (to the core) for individual logs ranged from 17 to $29 \mathrm{~h}$ when initial wood temperatures were between 14 and $24 \mathrm{C}$ (Table 2). The treatment time result for each log includes both vacuum time and extended 30-minute hold time. Treatment times for the three red oak logs averaged $24.7 \mathrm{~h}$. This time is substantially less than the time required for mandated export treatment of U.S. oak logs with methyl bromide for the eradication of the oak wilt fungus, Ceratocystis fagacearum (Schedule T312a, USDA Treatment Manual). Specifically, the USDA Treatment Manual recommends $72 \mathrm{~h}$ methyl bromide schedule to kill the pathogen in the sapwood of oak logs (USDA-APHIS-PPQ 2015). Treatment times are an important component of any economic assessment on methyl bromide alternative viability, and vacuum/steam has demonstrated a potential

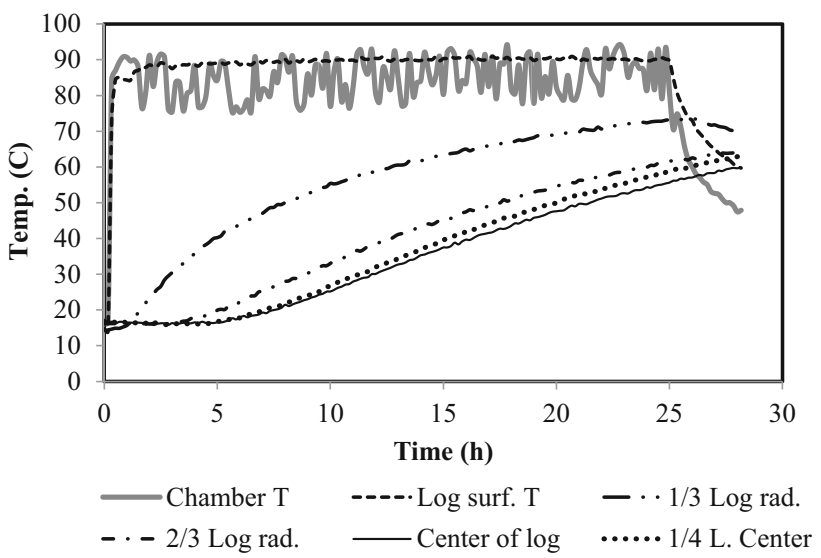

Fig. 4 Typical temperature profile of red oak (Quercus spp.) undergoing vacuum/steam treatment (Log id.\# 649171). Saturated steam at $90{ }^{\circ} \mathrm{C}$ was injected when target vacuum pressure $(200 \mathrm{mmHg})$ was reached

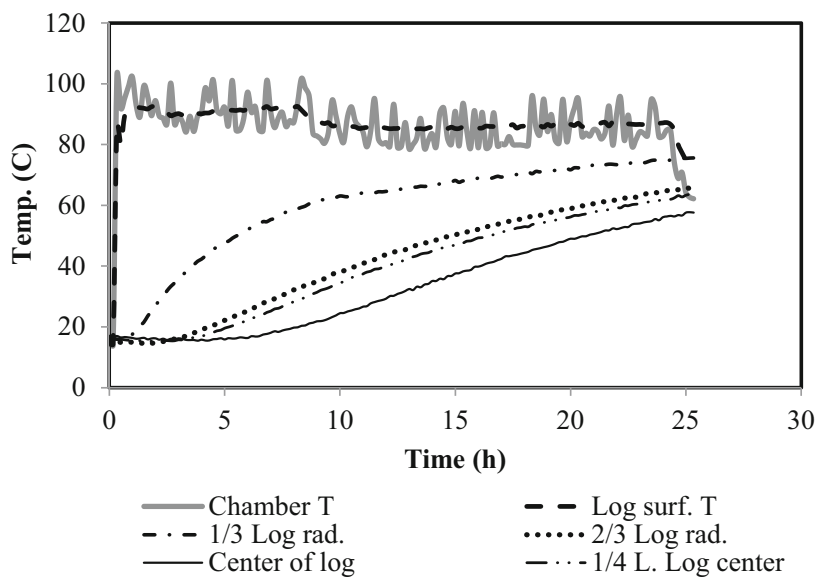

Fig. 5 Typical temperature profile of pignut hickory (Carya glabra) undergoing vacuum/steam treatment (Log id.\# 649334). Saturated steam at $90{ }^{\circ} \mathrm{C}$ was injected when target vacuum pressure $(200 \mathrm{mmHg})$ was reached

advantage in this regard. Verification of $C$. fagacearum pathogen elimination using a 56/30 vacuum-steam treatment schedule on symptomatic red oak logs is currently planned for 2016 in cooperation with the U.S. Forest Service.

Factors that would have effect on treatment time include initial temperature of the $\log (\mathrm{s})$, adequate heat source (steam flow), vacuum pump capacity, variations between log species (e.g. density, moisture content), and container insulation. An effort to explore any predictive relationship between $\log$ mass and treatment time that would allow for possible vacuum steam schedule development resulted in a relatively low correlation factor $\left(R^{2}=0.41, \mathrm{P}\right.$ values for slope and intercept are 0.01 and 0.92 , respectively, Fig. 6). Additional future studies should focus on adding replication for each species, with the ultimate goal of establishing a treatment schedule in a vacuum/steam container for 
Table 2 Total vacuum/steam treatment time in hours $\left(56{ }^{\circ} \mathrm{C} / 30 \mathrm{~min}\right.$ to core) for individual hardwood veneer logs

\begin{tabular}{|c|c|c|c|c|c|}
\hline Species & Log id. & Test number & Room temp. $\left({ }^{\circ} \mathrm{C}\right)$ & Wood initial temp. $\left({ }^{\circ} \mathrm{C}\right)$ & Treatment time (h) \\
\hline \multirow[t]{4}{*}{ Pignut Hickory } & 649322 & 3 & 23 & 24.3 & 22.00 \\
\hline & 649331 & Control sample & & & \\
\hline & 649333 & 6 & 15 & 15.8 & 29.33 \\
\hline & 649334 & 5 & 15 & 17.1 & 24.50 \\
\hline \multirow[t]{4}{*}{ Black Cherry } & 629246 & 14 & 19 & 14.5 & 26.53 \\
\hline & 649137 & 13 & 22 & 15.6 & 21.58 \\
\hline & 649325 & Control sample & & & \\
\hline & 649329 & 10 & 26 & 20.1 & 17.28 \\
\hline \multirow[t]{4}{*}{ Eastern Black Walnut } & 619480 & 4 & 25 & 22 & 24.50 \\
\hline & 619481 & 1 & 20 & 23.5 & 18.25 \\
\hline & 649323 & Control sample & & & \\
\hline & 649326 & 7 & 25 & 17.8 & 28.17 \\
\hline \multirow[t]{4}{*}{ Yellow -Poplar } & 646653 & 8 & 25 & 18.7 & 21.86 \\
\hline & 646676 & Control sample & & & \\
\hline & 646690 & 2 & 20 & 19.2 & 20.25 \\
\hline & 646707 & 9 & 25 & 20.5 & 24.5 \\
\hline \multirow[t]{4}{*}{ Red Oak } & 649171 & 15 & 21 & 16.7 & 23.62 \\
\hline & 649328 & 11 & 26 & 20.3 & 24.58 \\
\hline & 649330 & Control sample & & & \\
\hline & 704191 & 12 & 22 & 15.5 & 26.01 \\
\hline
\end{tabular}

Initial $200 \mathrm{mmHg}$ pressure and saturated steam at $90{ }^{\circ} \mathrm{C}$

multiple logs of similar diameter class. The heat tolerance and location of the pest in/on a particular log species are variables of particular importance in determining effective treatment times.

\subsection{Energy consumption during log vacuum steam treatment}

In addition to treatment time, overall energy used during the vacuum/steam process was calculated for each individual $\log$ tested, with primary emphasis on steam

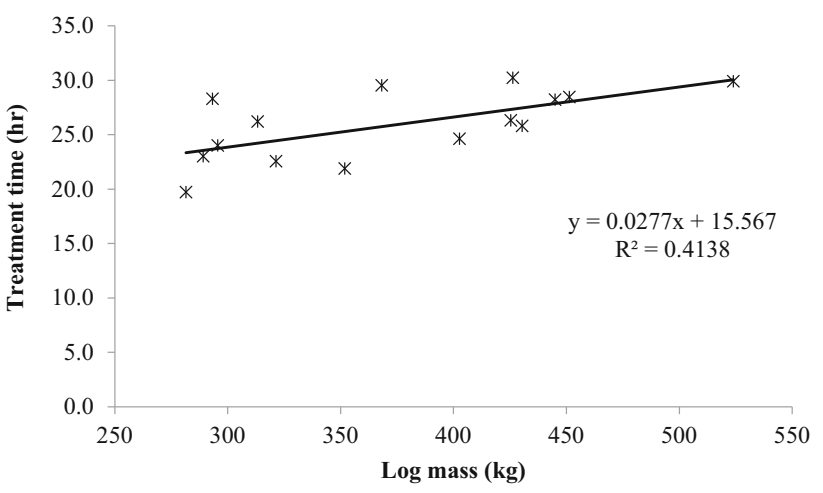

Fig. 6 The relationship between treatment time (h) and log mass $(\mathrm{kg})$ for 15 hardwood logs (p-values for slope and intercept are 0.01 and 0.92 respectively) production (Table 3). Electrical energy needed to power the vacuum pump was considered minor, and therefore, was not included in the calculations. Energy use ranged from 54 to $205 \mathrm{kWh}$ per log. This variation could be attributed to differences in log mass and species specific characteristics such as moisture content and density. Energy consumption is also influenced by the initial temperature of logs, as well as the degree of insulation provided in the treatment chamber. The energy consumption per unit weight per degree increase in log temperature was calculated, with similar variation observed (0.0052 to $0.0176 \mathrm{kWh} / \mathrm{kg} /{ }^{\circ} \mathrm{C}$ ) (Table 3). A poor correlation between energy consumption and log mass was found in this experiment $\left(R^{2}=0.17, \mathrm{P}\right.$ values are 0.12 for slope and 0.37 for intercept, respectively, Fig. 7). A more thorough and useful understanding of energy use should be obtained from experiments conducted in commercial sized insulated container with logs of the same species.

\subsection{Effect of vacuum steam treatment on log quality}

The only treatment-related defect visible on the study logs was an increase in the size of end checking (Fig. 8). Checking was observed to a depth of $2.5 \mathrm{~cm}$ following treatment. Log end checking appears to be species specific to some extent. Only slight end checking was found for black cherry, red oak and yellow-poplar logs following 
Table 3 Energy consumption for individual hardwood veneer logs treated with vacuum/steam

\begin{tabular}{|c|c|c|c|c|c|c|c|c|c|}
\hline Species & Log Id. & $\begin{array}{l}\text { Wood initial } \\
\text { temp. }\left({ }^{\circ} \mathrm{C}\right)\end{array}$ & $\begin{array}{l}\text { Small end } \\
\text { dia. }(\mathrm{cm})\end{array}$ & $\begin{array}{l}\text { Steam } \\
\text { used (kg) }\end{array}$ & $\begin{array}{l}\text { Log } \\
\text { weight } \\
\mathrm{kg} \text { ) }\end{array}$ & $\begin{array}{l}\text { Steam use } \\
\text { (kg/kgwood) }\end{array}$ & $\begin{array}{l}\text { KWh } \\
\text { used }\end{array}$ & $\begin{array}{l}\mathrm{KWh} / \mathrm{kg} \\
\text { wood }\end{array}$ & $\begin{array}{l}\mathrm{KWh} / \mathrm{kg} \text { wood } \\
\text { and }{ }^{\circ} \mathrm{C}\end{array}$ \\
\hline \multirow{3}{*}{$\begin{array}{l}\text { Pignut } \\
\text { Hickory }\end{array}$} & 649322 & 24.3 & 50.8 & 126 & 451 & 0.279 & 93.9 & 0.208 & 0.0066 \\
\hline & 649333 & 15.8 & 50.8 & 255 & 524 & 0.487 & 190.4 & 0.363 & 0.0090 \\
\hline & 649334 & 17.1 & 48.3 & 214 & 430 & 0.498 & 160.1 & 0.372 & 0.0096 \\
\hline \multirow[t]{3}{*}{ Black Cherry } & 629246 & 14.5 & 45.7 & 174 & 313 & 0.556 & 129.7 & 0.414 & 0.0100 \\
\hline & 649137 & 15.6 & 45.7 & 209 & 352 & 0.594 & 156.3 & 0.444 & 0.0110 \\
\hline & 649329 & 20.1 & 43.2 & 238 & 281 & 0.847 & 178.1 & 0.633 & 0.0176 \\
\hline \multirow{3}{*}{$\begin{array}{l}\text { Eastern Black } \\
\text { Walnut }\end{array}$} & 619480 & 22 & 45.7 & 171 & 368 & 0.465 & 127.9 & 0.347 & 0.0102 \\
\hline & 619481 & 23.5 & 43.2 & 150 & 289 & 0.519 & 111.8 & 0.387 & 0.0119 \\
\hline & 649326 & 17.8 & 48.3 & 275 & 426 & 0.646 & 205.4 & 0.482 & 0.0126 \\
\hline \multirow[t]{3}{*}{ Yellow Poplar } & 646653 & 18.7 & 45.7 & 151 & 296 & 0.510 & 112.7 & 0.381 & 0.0102 \\
\hline & 646690 & 19.2 & 45.7 & 127 & 321 & 0.396 & 94.9 & 0.295 & 0.0080 \\
\hline & 646707 & 20.5 & 43.2 & 73 & 293 & 0.249 & 54.4 & 0.186 & 0.0052 \\
\hline \multirow[t]{3}{*}{ Red Oak } & 649171 & 16.7 & 45.7 & 147 & 403 & 0.365 & 110.1 & 0.273 & 0.0070 \\
\hline & 649328 & 20.3 & 45.7 & 194 & 445 & 0.436 & 145.1 & 0.326 & 0.0091 \\
\hline & 704191 & 15.5 & 45.7 & 157 & 425 & 0.369 & 117.4 & 0.276 & 0.0068 \\
\hline Average & & 18.8 & 46.2 & 177 & 374.6 & 0.473 & 132.5 & 0.354 & 0.0097 \\
\hline
\end{tabular}

Initial $200 \mathrm{mmHg}$ pressure and saturated steam at $90{ }^{\circ} \mathrm{C}$

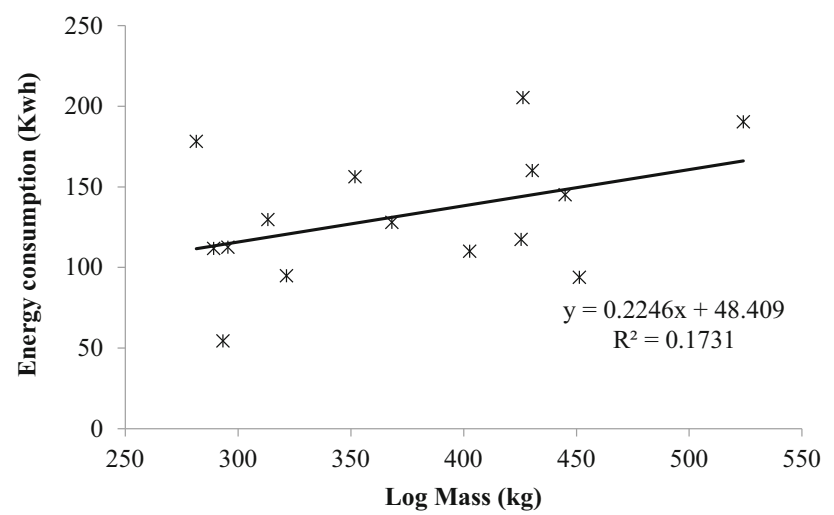

Fig. 7 The relationship between energy consumption (Kwh) and log mass $(\mathrm{kg})$ for 15 hardwood logs (p-values for slope and intercept are 0.12 and 0.37 , respectively)

treatment. Pignut hickory was the most prone to checking, while walnut exhibited a moderate increase in the observed preexisting end checking. It was noted that plastic log savers tended to fracture when stressed, so their use should be discouraged for $\log$ s treated with vacuum/steam. It is recommended that metal " $\mathrm{S}$ " iron savers be used in any future tests. The " $\mathrm{S}$ " iron savers are preferred for use on $\log s$ that are exported, and tend to be more effective on logs that are stored for extended periods prior to processing. Use of " $\mathrm{S}$ " iron savers for vacuum/steam treated logs would have no detrimental effect on the veneer production process. To prevent potential knife damage, log ends are

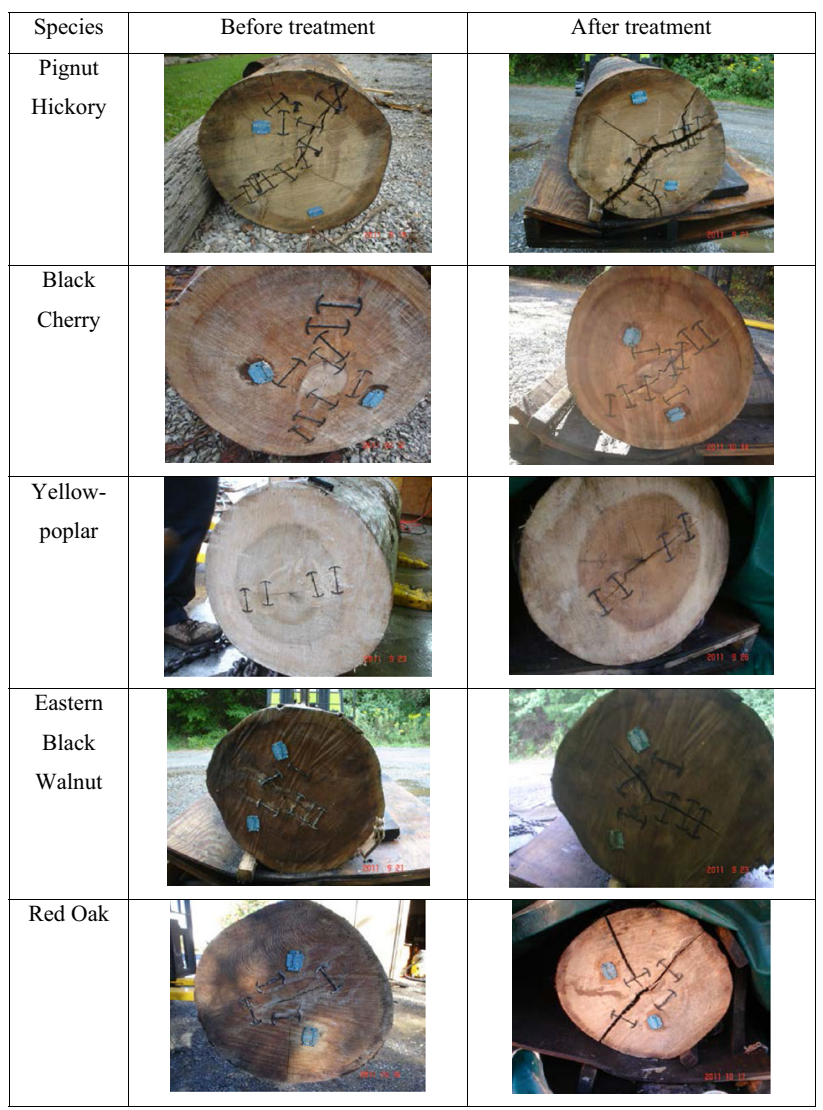

Fig. 8 Relative severity of end checking in hardwood veneer log species due to vacuum/steam treatment 
always trimmed during preparation for slicing as part of normal procedure.

\subsection{The effect of vacuum steam treatment on the veneer quality and veneer yields}

After slicing, three veneer samples were taken from each flitch. A total of twelve samples were collected from each species, with three of them from the control logs. All samples were examined for color change and other physical defects (e.g. checking) that could be attributed to the vacuum/steam process. When the veneers were graded, it was noted that the sapwood of hickory, yellow-poplar and black cherry became slightly darker due to treatment. The heartwood of cherry veneer samples was also rated as slightly darker after treatment. These observed differences were quite subtle and not deemed significant enough to affect veneer grade. The end checking of logs post treatment, particularly on susceptible species like pignut hickory and walnut, did not have any economic effect on veneer quality in the judgement of grading staff at Danzer Veneer.

The effect of log end checking on veneer yield was also examined. Again, grading staff indicated that end checking had no detrimental effect on yield of sliced veneer for any of the $\log$ species tested. The veneer manufacturer indicated that the veneer reject level and total veneer yield of treated logs and control logs was comparable on a log volume basis. Furthermore, reject level and yield of experimental logs was consistent with the veneer yield expected from routine commercial production.

\section{Conclusion}

A preliminary evaluation of vacuum/steam treatment on individual hardwood veneer logs in a flexible experimental chamber resulted in a number of findings that justify further development and evaluation of this technology. These include:

1. Treatment times on a number of hardwood veneer log species ranged from 17 to $29 \mathrm{~h}$ for an experimental schedule of $56{ }^{\circ} \mathrm{C}$ for $30 \mathrm{~min}$ to core. Variability was attributed to $\log$ size and species specific factors such as density and moisture content. These treatment times are a significant improvement over exposure times needed for existing methyl bromide schedules for high quality hardwood logs, with particular reference to the existing fumigation schedule for red oak treatment for oak wilt fungus elimination. This time reduction should be regarded as an important factor in gauging potential commercial viability moving forward.
2. Overall energy consumption was calculated for each individual log tested, but this data has limited usefulness at this point. A better indication of economic performance and potential commercial viability could be obtained through scaled testing that considers logs grouped in a commercial sized vacuum/steam chamber.

3. There was no appreciable effect on quality and yield of veneer from a commercial standpoint. Pignut hickory, and to a lesser extent walnut, displayed susceptibility to end checking of the log post treatment. It is recommended that " $\mathrm{S}$ " iron savers be used to control end checking during vacuum steam treatment of logs. Sapwood veneer of hickory, yellow-poplar and black cherry exhibited a slight darkening due to treatment, as did heartwood veneers of black cherry.

Given the current lack of alternatives to methyl bromide for log treatments, further development and evaluation of vacuum steam technology is warranted based on findings presented here. It is recommended that future vacuum steam treatment experiments of logs be conducted on a commercial scale, and ultimately target particular pests or pathogens of concern.

Acknowledgements This research was funded by USDA-APHISPPQ under contract number: 11-8130-009-CA.

\section{References}

ASTM D4442-15 (2015) "Standard Test Methods for Direct Moisture Content Measurement of Wood and Wood-Based Materials." ASTM International, West Conshohocken, PA, 2015, doi:10. 1520/D4442-15, www.astm.org

Cross DJ (1992) Penetration of methyl bromide in Pinus radiata wood and its significance for export quarantine. NZ J For Sci 21:235-245

Fleming MR, Bhardwaj MC, Janowiak JJ, Shield JE, Roy R, Agrawal DK, Bauer LS, Miller DL, Hoover K (2005) Noncontact ultrasound detection of exotic insects in wood packing materials. For Prod J 55(6):33-37

Haack RA, Jendek E, Liu H, Marchant KR, Petrice TR, Poland TM, Ye H (2002) The emerald ash borer: a new exotic pest in North America. Newslett Michigan Entomol Soc 47:1-5

IPPC (2002) Guideline for regulating wood packaging material in standard trade. Publication No. 15. March 2002. International Plant Protection Convention, IPPC Food and Agriculture Organization, Rome, Italy

IPPC (2009) International standards for phytosanitary measures: revision of ISPM No. 15, regulation of wood packaging material in international trade. International Plant Protection Convention, Food and Agriculture Organization of the United Nations, Rome, Italy

IPPC (2013) International standards for phytosanitary measures: ISPM 15, regulation of wood packaging material in international trade (2009) International Plant Protection Convention. Food and Agriculture Organization of the United Nations, Rome 
Mayfield AE, Fraedrich SW, Taylor A, Merten P, Myers SW (2014) Efficacy of heat treatment for the thousand cankers disease vector and pathogen in small black walnut logs. J Econ Entomol 107:174-184

Michelson A (1964) Diffusion of methyl bromide into pine wood during fumigation against Hylotrupes bajulus. Holzforschung und Holzverwertung 16:66-71

Simpson WT (2001) Heating times for round and rectangular cross sections of wood in steam. Gen. Tech. Rep. FPL-GTR-130.
Madison, WI: U.S. Department of Agriculture, Forest Service, Forest Products Laboratory. p 103

UNEP (2002) Information Paper on the Montreal Protocol Control Schedule and its Evolution. UNEP DTIE Ozone Action Programme. Tour Mira beau 39-43 quai Andre Citroen 73759 Paris Cedex 15 France

USDA-APHIS-PPQ (2015) USDA Treatment Manual. http://www. aphis.usda.gov/import_export/plants/manuals/ports/downloads/ treatment.pdf Section 5(4): pg. 30. Accessed 10 December 2015 